\title{
Astrocytic LRP1 Mediates Brain A $\beta$ Clearance and Impacts Amyloid Deposition
}

\author{
Chia-Chen Liu, ${ }^{1}$ Jin $\mathrm{Hu},{ }^{1,3} \mathrm{Na}$ Zhao, ${ }^{1}{ }^{-}$Jian Wang, ${ }^{1}$ Na Wang, ${ }^{1,3}$ ㅇohn R. Cirrito, ${ }^{2}$ Takahisa Kanekiyo, \\ David M. Holtzman, ${ }^{2}$ and Guojun $\mathrm{Bu}^{1,3}$ \\ ${ }^{1}$ Department of Neuroscience, Mayo Clinic, Jacksonville, Florida 32224, ${ }^{2}$ Department of Neurology, Hope Center for Neurological Disorders, Knight \\ Alzheimer's Disease Research Center, Washington University School of Medicine, St. Louis, Missouri 63110, and ${ }^{3}$ Fujian Provincial Key Laboratory of \\ Neurodegenerative Disease and Aging Research, Institute of Neuroscience, College of Medicine, Xiamen University, Xiamen, Fujian, 361102 China
}

Accumulation and deposition of amyloid- $\beta(\mathrm{A} \beta)$ in the brain represent an early and perhaps necessary step in the pathogenesis of Alzheimer's disease (AD). $A \beta$ accumulation leads to the formation of $A \beta$ aggregates, which may directly and indirectly lead to eventual neurodegeneration. While $\mathrm{A} \beta$ production is accelerated in many familial forms of early-onset $\mathrm{AD}$, increasing evidence indicates that impaired clearance of $\mathrm{A} \beta$ is more evident in late-onset $\mathrm{AD}$. To uncover the mechanisms underlying impaired $\mathrm{A} \beta$ clearance in $\mathrm{AD}$, we examined the role of low-density lipoprotein receptor-related protein 1 (LRP1) in astrocytes. Although LRP1 has been shown to play critical roles in brain $\mathrm{A} \beta$ metabolism in neurons and vascular mural cells, its role in astrocytes, the most abundant cell type in the brain responsible for maintaining neuronal homeostasis, remains unclear. Here, we show that astrocytic LRP1 plays a critical role in brain A $\beta$ clearance. LRP1 knockdown in primary astrocytes resulted in decreased cellular A $\beta$ uptake and degradation. In addition, silencing of LRP1 in astrocytes led to downregulation of several major A $\beta$-degrading enzymes, including matrix metalloproteases MMP2, MMP9, and insulin-degrading enzyme. More important, conditional knock-out of the Lrp1 gene in astrocytes in the background of APP/PS1 mice impaired brain $\mathrm{A} \beta$ clearance, exacerbated $\mathrm{A} \beta$ accumulation, and accelerated amyloid plaque deposition without affecting its production. Together, our results demonstrate that astrocytic LRP1 plays an important role in A $\beta$ metabolism and that restoring LRP1 expression and function in the brain could be an effective strategy to facilitate $\mathrm{A} \beta$ clearance and counter amyloid pathology in $\mathrm{AD}$.

Key words: Alzheimer's disease; amyloid- $\beta$; LRP1

\section{Significance Statement}

Astrocytes represent a major cell type regulating brain homeostasis; however, their roles in brain clearance of amyloid- $\beta(\mathrm{A} \beta)$ and underlying mechanism are not clear. In this study, we used both cellular models and conditional knock-out mouse models to address the role of a critical $A \beta$ receptor, the low-density lipoprotein receptor-related protein 1 (LRP1) in astrocytes. We found that LRP1 in astrocytes plays a critical role in brain $A \beta$ clearance by modulating several $A \beta$-degrading enzymes and cellular degradation pathways. Our results establish a critical role of astrocytic LRP1 in brain A $\beta$ clearance and shed light on specific $\mathrm{A} \beta$ clearance pathways that may help to establish new targets for AD prevention and therapy.

\section{Introduction}

Astrocytes, as scaffolds supporting brain structural integrity, represent one of the major cell types regulating diverse brain functions.

Received Nov. 7, 2016; revised Feb. 27, 2017; accepted March 2, 2017.

Author contributions: C.-C.L., J.H., N.Z., J.R.C., T.K., D.M.H., and G.B. designed research; C.-C.L., J.H., N.Z., J.W., and N.W. performed research; J.R.C. contributed unpublished reagents/analytic tools; C.-C.L., J.H., N.Z., J.W., and N.W. analyzed data; C.C.L. and G.B. wrote the paper.

This work was supported by National Institutes of Health Grants R01AG027924, R01AG046205, RF1AG051504, R01AG035355, and P50AG016574 to G.B., P01NS074969 to G.B., J.R.C., and D.M.H., Cure Alzheimer's Foundation Grant to G.B., American Heart Association Grant 15SDG22460003 to T.K., and American Heart Association Fellowship to C.-C.L. We thank Dr. Mingjie Li and Nada Husic (Washington University Viral Vectors Core) for producing the lentiviruses; Dr. Pritam Das for providing the $\gamma$-secretase inhibitor LY411575; and Dr. Dennis Dickson, Monica Castanedes Casey, Linda Rousseau, and Virginia Phillips for histology and immunohistochemical analyses.

The authors declare no competing financial interests.
Through their bidirectional interactions with neurons, astrocytes actively regulate neuronal signaling pathways in addition to maintaining synaptic homeostasis by modulating the extracellular ionic environment and providing nutrients/metabolites for neurons (Wang and Bordey, 2008; Sofroniew and Vinters, 2010; Osborn et al., 2016). Astrocytes also significantly contribute to immune responses as evidenced by their coupling with microglia in neurodegenerative diseases, including Alzheimer's disease $(\mathrm{AD})$ (Sofroniew and Vinters, 2010; Meraz-Ríos et al., 2013). Indeed, astrogliosis ac-

Correspondence should be addressed to either Dr. Guojun Bu or Dr. Chia-Chen Liu, Department of Neuroscience, Mayo Clinic, 4500 San Pablo Road, Jacksonville, FL32224. E-mail: bu.guojun@mayo.edu or liu.chiachen@mayo.edu DOI:10.1523/JNEUROSCI.3442-16.2017

Copyright $\odot 2017$ the authors $\quad 0270-6474 / 17 / 374023-09 \$ 15.00 / 0$ 
companied by the upregulation of GFAP and hypertrophic processes of astrocytes surrounding senile plaques are pathological hallmark of AD (Osborn et al., 2016).

$\mathrm{AD}$ is characterized by progressive neurodegeneration, resulting in dementia (Alzheimer'sAssociation, 2015). The accumulation and deposition of amyloid- $\beta$ (A $\beta)$ peptides cleaved from amyloid precursor protein (APP) in the brain likely are central in AD development and progression (Hardy and Selkoe, 2002; Blennow et al., 2006; Zheng and Koo, 2011). In AD brains, astrogliosis has been shown to increase linearly with disease progression, which negatively correlates with cortical thickness (Serrano-Pozo et al., 2011). On the other hand, attenuation of astrocyte activation by deleting GFAP and vimentin exacerbates amyloid plaque pathogenesis in amyloid model mice (Kraft et al., 2013), suggesting that astrocytes may play an important role in $\mathrm{A} \beta$ metabolism.

Astrocyte-regulated $\mathrm{A} \beta$ metabolism involves multiple mechanisms (Wyss-Coray et al., 2003; Nielsen et al., 2010), with the low-density lipoprotein receptor (LDLR) family members, specifically LDLR-related protein 1 (LRP1), likely playing a critical role. LRP1, a multiligand single transmembrane receptor, has been shown to regulate brain $\mathrm{A} \beta$ metabolism (Kanekiyo and $\mathrm{Bu}$, 2014), whereas its antagonist, receptor-associated protein (RAP), significantly suppresses $\mathrm{A} \beta$ degradation by astrocytes (Koistinaho et al., 2004). Conditional deletion of the Lrp1 gene in neurons (Kanekiyo et al., 2013), vascular mural cells (Kanekiyo et al., 2012), and endothelial cells (Storck et al., 2016) aggravates $A \beta$ deposition in amyloid model mice. Despite the fact that LRP1 is abundantly expressed in astrocytes, the contribution of LRP1 to $\mathrm{A} \beta$ metabolism in astrocytes has not been well studied in vivo. Here, using cellular and conditional knock-out mouse models, we show that LRP1 deficiency in astrocytes disturbed $A \beta$ metabolism through several pathways, leading to exacerbated amyloid pathology.

\section{Materials and Methods}

Animal and preparation of brain homogenates. All animal procedures were approved by the Institutional Animal Care and Use Committee at Mayo Clinic and in accordance with the regulations of the American Association for the Accreditation of Laboratory Animal Care. Astrocytespecific $\operatorname{Lrp1-KO}$ mice $\left(\mathrm{aLrp1} 1^{-1-}\right)$ were generated by breeding the $\operatorname{Lrp1}$ floxed mice (Rohlmann et al., 1998) with GFAP-driven Cre recombinase mice (obtained from NCI Mouse Repository) (Bajenaru et al., 2002), and further bred into the background of $\mathrm{APP}_{\mathrm{SWE}} / \mathrm{PS} 1 \Delta \mathrm{E} 9$ amyloid mouse model (Jankowsky et al., 2004) (hereafter referred to as APP/PS1). Littermates (including both male and female mice) of control APP/PS1 and APP/PS1 mice lacking LRP1 in astrocytes (APP/PS1; $\mathrm{LLrp1}^{-/-}$) were used. In a separate experiment, littermates of control and astrocytic LRP1 knock-out mice $\left(\mathrm{aLrp1} 1^{-/-}\right.$) without the APP/PS1 background were used. Brain tissues were dissected and kept frozen at $-80^{\circ} \mathrm{C}$ until further analysis. Some brain tissues were fixed in $10 \%$ neutralized formalin for histological analysis. Mouse brain tissues for $\mathrm{A} \beta$ analysis were processed through sequential extraction as described previously (Liu et al., 2014).

Cell culture, lentivirus-delivered RNA interference, and A $\beta$ ELISA anal$y$ sis. Neonatal mouse primary astrocytes and adult mouse astrocytes were prepared as described previously (Koistinaho et al., 2004; Zhao et al., 2014). LRP1-specific shRNAs were purchased from Sigma, and lentiviruses were produced in the Viral Vectors Core facility at Washington University School of Medicine. In brief, 293T cells were transfected with pLKO.1-derived constructs together with the pHR8.2 and pCMVVSV-G packaging systems as previously described (Stewart et al., 2003). Nontarget shRNA was used as a control. A $\beta$ levels in the mouse brain lysates were determined by ELISA (Youmans et al., 2011; Das et al., 2012) with end-specific mAb 2.1.3 (human $\mathrm{A} \beta \mathrm{x}-42$ specific) and $\mathrm{mAb}$ 13.1.1 (human $\mathrm{A} \beta \mathrm{x}-40$ specific) for capture and HRP-conjugated $\mathrm{mAb}$ Ab5 (human $\mathrm{A} \beta 1-16$ specific) for detection. The ELISAs were developed using Super Slow ELISA TMB (Sigma).
FACS-based internalization and binding assays, and $A \beta$ degradation assay. $\mathrm{A} \beta 42$ and FAM-A $\beta 42$ were purchased from AnaSpec, and the experiments were performed as described previously (Kanekiyo et al., 2011). Cells were incubated with FAM-A $\beta 42(500 \mathrm{nM})$ at $37^{\circ} \mathrm{C}$ for different period of time in DMEM with 10\% FBS for internalization assay. Cells were removed from the plate using Cell Dissociation Solution (Sigma) and then washed and resuspended in PBS containing 1.5\% FBS, $1 \%$ sodium azide, and 1\% PFA. Cells were analyzed for fluorescence on a BD FACSCalibur machine (BD Biosciences). Unstained cells without any exposure to fluorescence were used as a control for background fluorescence. For binding assays, cells were incubated with FAM-A $\beta 42$ (200 or $500 \mathrm{nM})$ at $4^{\circ} \mathrm{C}$ for $2 \mathrm{~h}$, suspended by cell dissociation solution, and subjected to FACS analysis. For $\mathrm{A} \beta$ degradation assay, cells were allowed to internalize $\mathrm{A} \beta 42(1 \mu \mathrm{M})$ for $2 \mathrm{~h}$ at $37^{\circ} \mathrm{C}$. Cultures were washed and incubated in medium lacking $\mathrm{A} \beta 42$ for an additional $6 \mathrm{~h}$. Cells were then dissolved in guanidine in $50 \mathrm{~mm}$ Tris- $\mathrm{HCl}, \mathrm{pH} 8.0$, and cell-associated $\mathrm{A} \beta$ levels were analyzed by ELISA.

Immunohistochemical and immunofluorescent staining. Paraffinembedded sections were immunostained using pan- $\mathrm{A} \beta$ ( $\mathrm{A} \beta$ 33.1.1; human A $\beta$ 1-16 specific), anti-GFAP (BioGenex), and anti-ionized calcium-binding adaptor molecule 1 (Iba-1) (Wako) antibodies (Liu et al., 2016). Immunohistochemically stained sections were captured using the ImageScope AT2 image scanner (Aperio Technologies) and analyzed using the ImageScope software. The immunoreactivities of GFAP and Iba-1 staining in the hippocampus were calculated using the Positive Pixel Count Algorithm available with the ImageScope software (Aperio Technologies). For double immunostaining, deparaffinized sections were preincubated with citrate buffer $(10 \mathrm{~mm}$ sodium citrate buffer with $0.05 \%$ Tween $20, \mathrm{pH} 6.0$ ) at $95^{\circ} \mathrm{C}$ for $20 \mathrm{~min}$. They were incubated at $4^{\circ} \mathrm{C}$ overnight with a rabbit anti-LRP1 antibody (Bu et al., 1995) and a mouse anti-NeuN antibody (Millipore) or a mouse anti-GFAP antibody (Millipore), followed by Alexa488- or Alexa568-conjugated secondary antibodies (Invitrogen) for $2 \mathrm{~h}$ at room temperature. The images were captured by confocal laser-scanning fluorescence microscopy (model LSM510 invert; Carl Zeiss) (Fu et al., 2016).

In vivo microdialysis. To assess interstitial fluid (ISF) $\mathrm{A} \beta$ in the hippocampus of awake, freely moving APP/PS1 and APP/PS1; aLrp1 $1^{-/-}$ mice, in vivo microdialysis was performed as previously described (Cirrito et al., 2011; Liu et al., 2016). Briefly, under isoflurane volatile anesthetic, guide cannula (BR style; Bioanalytical Systems) were cemented into the hippocampus ( $3.1 \mathrm{~mm}$ behind bregma, $2.5 \mathrm{~mm}$ lateral to midline, and $1.2 \mathrm{~mm}$ below dura at a $12^{\circ}$ angle). A microdialysis probe (38 kDa molecular weight cutoff membrane; Bioanalytical Systems) was inserted through the guide cannula into the brain. ACSF $\left(1.3 \mathrm{~mm} \mathrm{CaCl}_{2}\right.$, $1.2 \mathrm{mM} \mathrm{MgSO}_{4}, 3 \mathrm{~mm} \mathrm{KCl}, 0.4 \mathrm{~mm} \mathrm{KH}_{2} \mathrm{PO}_{4}, 25 \mathrm{~mm} \mathrm{NaHCO}_{3}$, and 122 $\mathrm{mm} \mathrm{NaCl}, \mathrm{pH} 7.4$ ) containing $4 \% \mathrm{BSA}$ (Sigma) filtered through a $0.1 \mu \mathrm{m}$ membrane was used as microdialysis perfusion buffer. Flow rate was a constant $1.0 \mu \mathrm{l} / \mathrm{min}$. Samples were collected every 60-90 min overnight, which gets through the $4-6 \mathrm{~h}$ recovery period, and the mean concentration of $A \beta$ over the $6 \mathrm{~h}$ preceding treatment was defined as basal levels of ISF A $\beta$. Sample were collected through a refrigerated fraction collector and assessed for $\mathrm{A} \beta 40$ by ELISA as described previously (Cirrito et al., 2011).

Western blotting. Samples were homogenized and incubated in TBS containing 1\% TX-100, supplemented with protease inhibitor. The detailed procedures were performed as previously described (Liu et al., 2015). The following antibodies were used in this study: in-house antiLRP1 antibody (Bu et al., 1995), anti-GFAP (Millipore), 6E10 (Covance) for total APP, anti-sAPP $\alpha$ (IBL-America), anti-human sAPP $\beta$ (IBLAmerica), aquaporin-4 (AQP-4; Millipore), and anti- $\beta$-actin (Sigma) antibodies.

RNA isolation and real-time PCR analysis. Total RNA was isolated by using Trizol (QIAGEN), RNeasy Mini Kit (QIAGEN) and subjected to DNase I digestion to remove contaminating genomic DNA. Total RNA was dissolved in nuclease-free water and stored at $-80^{\circ} \mathrm{C}$. Reverse transcription was performed using a SuperScript III reverse transcriptase (Invitrogen). Primer sequences were as previously described (Liu et al., 2016). The set of actin primers was used as an internal control for each 

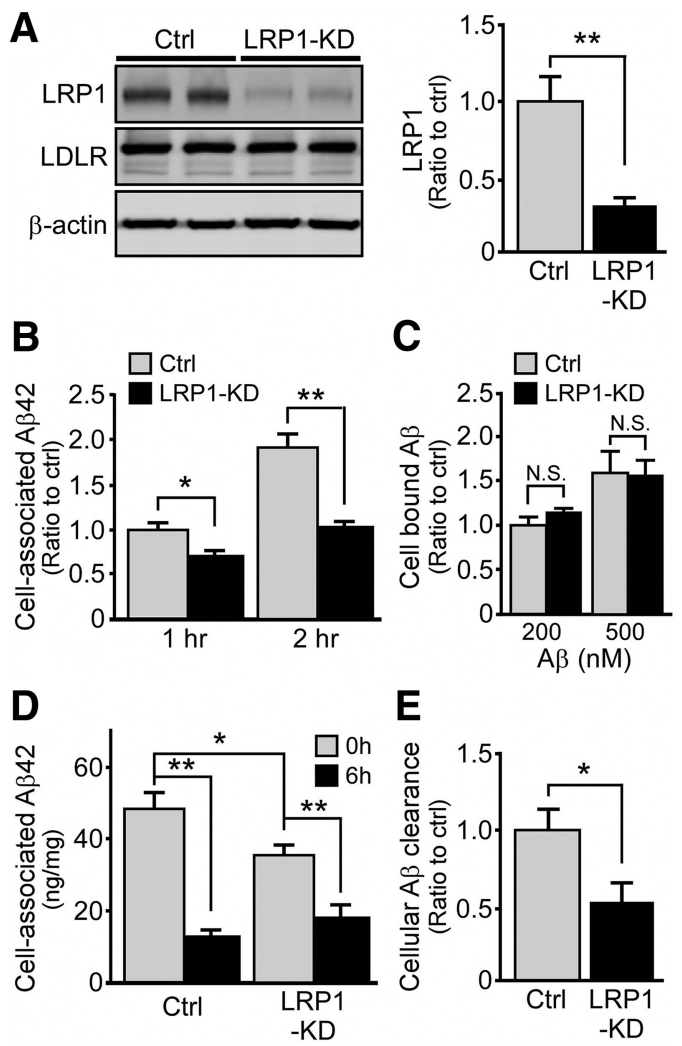

Figure 1. LRP1 mediates $A \beta$ uptake and degradation in primary astrocytes. $A$, Mouse primary astrocytes were transduced with lentiviral mediated control or LRP1 shRNA and were analyzed $48 \mathrm{~h}$ after transfection. Western blotting showed that LRP1 expression was significantly downregulated in primary astrocytes. ${ }^{* *} p<0.01$ (two-tailed Student's $t$ test). $\boldsymbol{B}$, Primary astrocytes with or without LRP1 knockdown were incubated with FAM-A $\beta 42(500 \mathrm{~nm})$ for 1 or $2 \mathrm{~h}$ at $37^{\circ} \mathrm{C}$, and the cell-associated $A \beta 42$ was analyzed by FACS. Representative results of five independent experiments performed in triplicate are shown. ${ }^{* *} p<0.01$ (two-way ANOVA). C, Primary astrocytes with or without LRP1 knockdown were incubated with FAM$\mathrm{A} \beta 42$ (200 or $500 \mathrm{~nm})$ for $2 \mathrm{~h}$ at $4^{\circ} \mathrm{C}$ and analyzed by FACS. Representative results from three independent experiments performed in triplicate are shown. $\boldsymbol{D}$, Control and LRP1-KD astrocytes were allowed to internalize $A \beta 42(1 \mu \mathrm{M})$ for $2 \mathrm{~h}$ at $37^{\circ} \mathrm{C}$ (gray bars); parallel cultures were washed and incubated for an additional $6 \mathrm{~h}$ in medium lacking $\mathrm{A} \beta 42$ (black bars) and analyzed by ELISA. ${ }^{*} p<0.05$ (two-way ANOVA). ${ }^{* *} p<0.01$ (two-way ANOVA). $\boldsymbol{E}$, The decrease of internalized $A \beta$ is estimated as cellular clearance. Data are mean $\pm S D$. ${ }^{*} p<0.05$ (two-tailed Student's $t$ test).

specific gene amplification. The relative expressions were quantified and analyzed by using Bio-Rad iCycler.

Statistical analysis. All quantified data represent an average of samples. Statistical significance was determined by two-tailed Student's $t$ test or ANOVA with a Tukey's post-test, and $p<0.05$ was considered significant.

\section{Results}

LRP1 regulates $A \boldsymbol{\beta}$ metabolism in astrocytes

To determine the role of astrocytic LRP1 in A $\beta$ metabolism, we first examined whether LRP1 downregulation in astrocytes impacts cellular $\mathrm{A} \beta$ uptake. Using lentiviral-mediated control or LRP1 shRNA, we successfully knocked down LRP1 in mouse primary astrocytes as confirmed by Western blot (Fig. 1A). Control or LRP1-knockdown (KD) astrocytes were incubated with $500 \mathrm{~nm}$ FAM-labeled A $\beta 42$ for 1 or $2 \mathrm{~h}$ at $37^{\circ} \mathrm{C}$, and cell-associated $\mathrm{A} \beta$ was assessed by FACS. We found that $\mathrm{A} \beta 42$ uptake in LRP1-KD cells was significantly reduced compared with control cells following incubation with $\mathrm{A} \beta 42$ for $1 \mathrm{~h}$, whereas this effect was more prominent after $2 \mathrm{~h}$ treatment (Fig. $1 B$ ). To investigate whether LRP1 mediates the binding of A $\beta 42$ to astro-
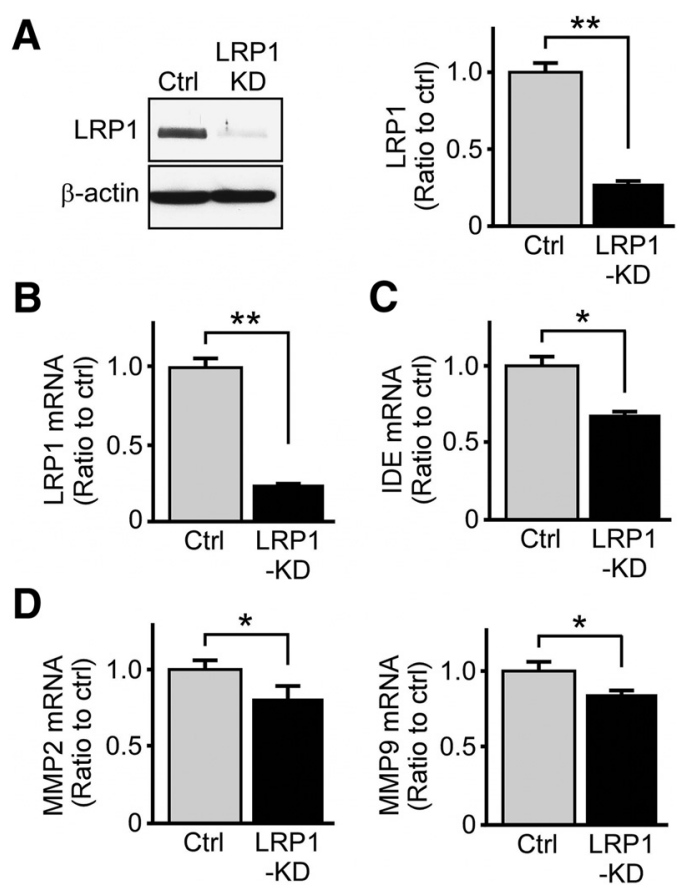

Figure 2. LRP1 downregulation in astrocytes suppresses the expression of major $A \beta$ degrading enzymes. $\boldsymbol{A}, \boldsymbol{B}, \mathrm{LRP1}$ was significantly knocked down in primary astrocytes as assessed by Western blot and real-time PCR. Data are mean \pm SEM. ${ }^{* *} p<0.01$. C, $\boldsymbol{D}$, The mRNA levels of IDE, MMP2, and MMP9 in control and LRP1-KD primary astrocytes examined by real-time $P C R$. Representative results from three independent experiments performed in quadruplicate are shown. Data are mean \pm SEM. ${ }^{*} p<0.05$ (two-tailed Student's $t$ test).

cytes, primary astrocytes were incubated with different concentrations of FAM-A $\beta 42$ for $2 \mathrm{~h}$ at $4^{\circ} \mathrm{C}$ to prevent cellular uptake. We found that downregulation of LRP1 did not have a significant effect on $\mathrm{A} \beta 42$ binding to the cell surface of astrocytes as assessed by FACS (Fig. 1C). To determine whether LRP1 mediates the degradation of $\mathrm{A} \beta$, primary astrocytes were incubated with $\mathrm{A} \beta 42$ for $2 \mathrm{~h}$ at $37^{\circ} \mathrm{C}$. The $A \beta$ in the medium was then removed, and the fate of $A \beta$ in the cells was chased for $6 \mathrm{~h}$. Cell-associated $\mathrm{A} \beta 42$ was cleared following $6 \mathrm{~h}$ of incubation in both control and LRP1-KD astrocytes (Fig. 1D). However, $A \beta$ was cleared to a lesser extent in LRP1-KD astrocytes compared with control cells (Fig. $1 E$ ). These results demonstrate that LRP1 regulates the uptake and subsequent degradation of $A \beta$ in astrocytes.

To investigate whether LRP1 modulates $A \beta$ metabolism through extracellular $A \beta$-degrading proteases, such as insulindegrading enzyme (IDE) (Leissring et al., 2003) and matrix metalloproteinases (MMPs) (Backstrom et al., 1996), we evaluated the levels of these major enzymes following LRP1 knockdown. Of note, previous studies demonstrated that MMP2 and MMP9 expressed by astrocytes mediate extracellular $\mathrm{A} \beta$ catabolism (Yin et al., 2006), and LRP1 regulates MMP2 and MMP9 expression in glioblastomas cells (Song et al., 2009). Upon lentiviral-mediated knockdown of LRP1 expression by $>70 \%$ (Fig. $2 A, B$ ), we found that the levels of IDE, MMP2, and MMP9 were significantly reduced (Fig. 2C,D). As such, LRP1 might also affect extracellular degradation of $\mathrm{A} \beta$ through the modulation of these degrading enzymes.

\section{Conditional knock-out of $\operatorname{Lrp} 1$ in astrocytes exacerbates $\mathrm{A} \boldsymbol{\beta}$ deposition in APP/PS1 amyloid model mice}

To examine the effect of astrocytic LRP1 deletion on A $\beta$ metabolism in vivo, we conditionally disrupted the expression of the Lrp1 gene in 
A

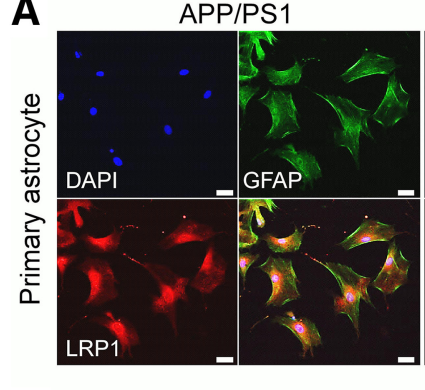

C

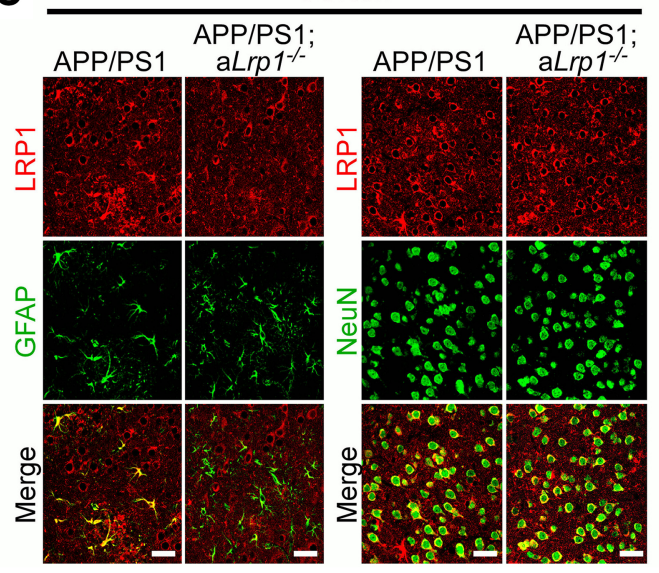

APP/PS1: aLro1 1

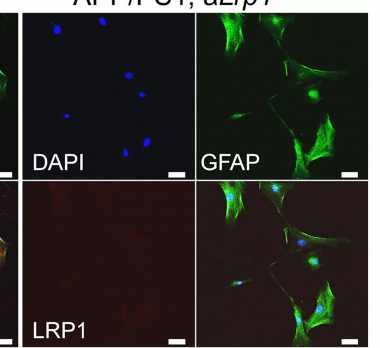

AP
B

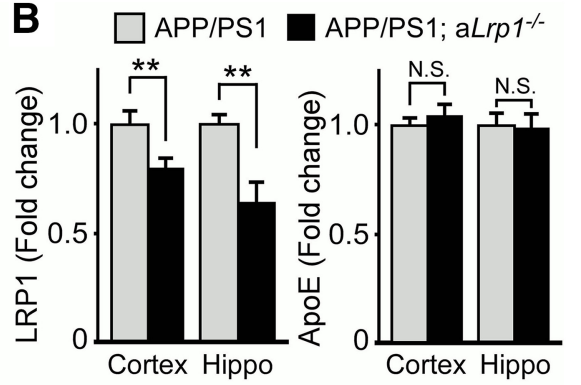

Hippo

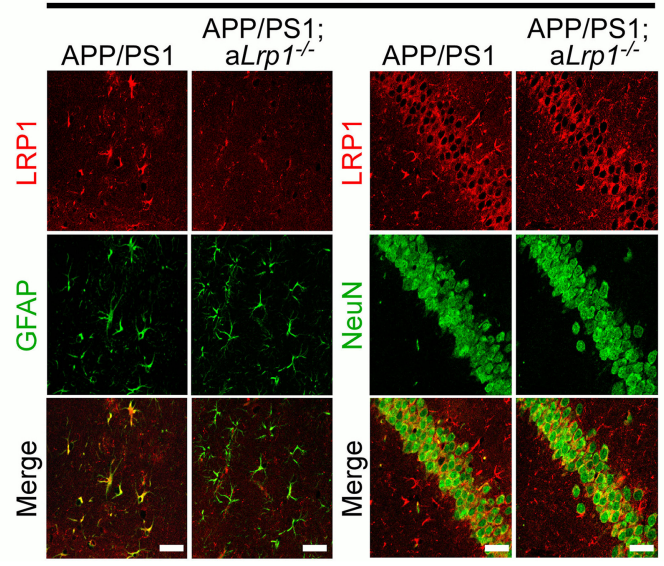

Figure 3. Astrocytic LRP1 deletion in APP/PS1; aLrp1 ${ }^{-1-}$ mice. Astrocyte-specific LRP1-KO mice were generated by crossing the Lrp $1^{\text {flox } f l o x}$ mice with GFAP-Cre mice, and further bred into an APP/PS1 background. A, Adult astrocytes were established from APP/PS1 and APP/PS1; aLrp1 $1^{-/-}$mice (2-3 months of age). The astrocytes were costained with a rabbit anti-LRP1 antibody and a mouse anti-GFAP antibody. Scale bar, $50 \mu \mathrm{m} . \boldsymbol{B}$, Brain LRP1 and apoE levels in the cortex ( $n=9 /$ group) and hippocampus $(n=6-10 / \mathrm{group})$ of APP/PS1 and APP/PS1; alrp $1^{-/-}$mice were quantified by Western blot analysis. Data are mean \pm SEM. ${ }^{* *} p<0.01$. C, Cortical and hippocampal slides from control APP/PS1 and APP/PS1; aLrp1 ${ }^{-/-}$mice were costained with an LRP1 antibody and a neuronal marker anti-NeuN or an astrocyte marker anti-GFAP, respectively. Scale bar, $50 \mu \mathrm{m}$. The colocalization of the immunoreactivities of LRP1 and GFAP is abundant in sections from APP/PS1 mice but minimum in those from APP/PS1; $a L r p 1^{-1-}$ mice. Colocalization with neuronal marker NeuN was not affected by astrocytic LRP1 deletion.

astrocytes by crossing $\operatorname{Lrp} 1^{\text {flox/flox }}$ mice with GFAP-Cre mice (Bajenaru et al., 2002), and further bred these mice to the APP/PS1 amyloid mouse model (Jankowsky et al., 2004). To confirm deletion of LRP1 in astrocytes, we performed immunofluorescent staining for LRP1 and GFAP in adult astrocyte cultures derived from control $\mathrm{APP} / \mathrm{PS} 1$ and APP/PS1 mice lacking LRP1 in astrocytes (APP/PS1; aLrp $\left.1^{-/-}\right)$. We found the LRP1 signal was significantly diminished in GFAP-positive astrocytes (Fig. 3A). Western blot analysis also revealed significantly reduced levels of LRP1 in cortex and hippocampus of APP/PS1; aLrp1 $1^{-/-}$mice compared with APP/PS1 mice (Fig. $3 B$ ), consistent with the notion that LRP1 is depleted in astrocytes. The remaining LRP1 expression in APP/PS1; $\mathrm{aLrp1} 1^{-/-}$ mice likely represents those in neurons and in cells composed of cerebrovasculature. Astrocytic LRP1 deletion did not affect brain apolipoprotein E (apoE) levels in both cortex and hippocampus (Fig. $3 B$ ), whereas our previous study showed that neuronal LRP1 knock-out results in increased apoE (Liu et al., 2007), thus differentiating the effects of astrocytic and neuronal LRP1 deletion. To further confirm the specificity of LRP1 deletion, the brain tissues obtained from 12-month-old APP/PS1 and APP/PS1; aLrp1 ${ }^{-/-}$ mice were stained with an LRP1-specific antibody together with astrocyte-specific (GFAP) and neuron-specific (NeuN) markers. In both cortex and hippocampus of APP/PS1 mice, LRP1 was abundantly expressed in neurons and astrocytes, whereas LRP1 in APP/ PS1; aLrp1 $1^{-/-}$mice was specifically deleted in astrocytes (Fig. 3C). Importantly, immunohistochemical staining revealed that the amyloid plaque deposition in APP/PS1; aLrp1 $1^{-/-}$mice was significantly higher than that of control APP/PS1 mice at 12 months of age (Fig. $4 A)$. In addition, soluble $\mathrm{A} \beta$ concentrations were significantly higher in APP/PS1; $\mathrm{aLrp1}^{-/-}$mice than in APP/PS1 mice (Fig. 4B,C), as assessed by ELISA following fractionation of cortical and hippocampal brain tissues into TBS-soluble, detergent-soluble, and insoluble (guanidine-HCl, GDN) fractions (Youmans et al., 2011). Consistent with increased amyloid deposition, the concentrations of insoluble $\mathrm{A} \beta 40$ and $\mathrm{A} \beta 42$ in guanidine fractions were increased in the cortex and hippocampus of APP/PS1; aLrp1 $1^{-/-}$mice (Fig. $4 B, C$ ), suggesting that astrocytic LRP1 plays an important role in regulating amyloid deposition.

LRP1 deletion in astrocytes suppresses $A \beta$ clearance without affecting $A \boldsymbol{\beta}$ production in amyloid model mice

To determine whether astrocytic LRP1 affects $A \beta$ metabolism in vivo, we first measured ISF $\mathrm{A} \beta$ concentration in the hippocampus of APP/PS1 and APP/PS1; aLrp1 $1^{-/-}$mice at 3-4 months of age using in vivo microdialysis. Soluble $\mathrm{A} \beta$ found in ISF, which is exchangeable across a dialysis membrane, significantly correlates with total soluble $A \beta$ in brain extracellular pools (Cirrito et al., 2003). Baseline concentrations of ISF $A \beta 40$ trended higher in $\mathrm{APP} / \mathrm{PS} 1$; $\mathrm{a} L r p 1^{-/-}$mice, likely due to impaired $\mathrm{A} \beta$ clearance resulting from deletion of astrocytic LRP1 (Fig. $5 A$ ). To directly measure the elimination rate of ISF $\mathrm{A} \beta$, mice were treated with a potent $\gamma$-secretase inhibitor to rapidly block $\mathrm{A} \beta$ production, and ISF $A \beta$ was gradually decreased in a time-dependent manner. We found that the half-life of ISF A $\beta 40$ was slightly but significantly increased in APP/PS1; aLrp1 $1^{-/-}$mice (Fig. $5 B$ ), indicating that deletion of LRP1 in astrocytes may impair elimination of soluble $\mathrm{A} \beta$ from the ISF. To examine whether LRP 1 deletion in astrocytes affects APP processing, the levels of full-length APP and APP 
A

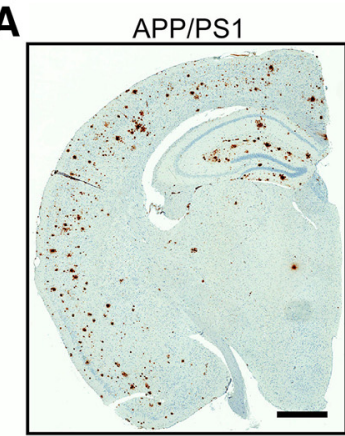

B
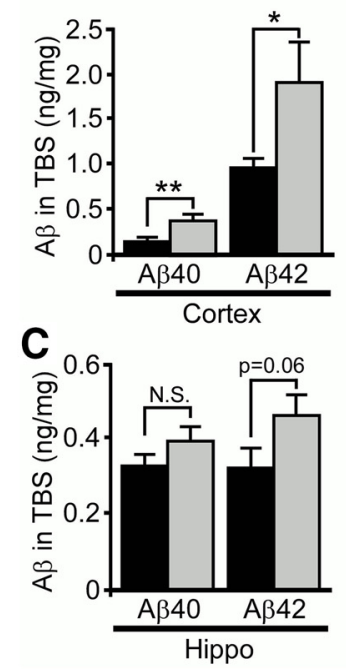

APP/PS1; aLrp1\%-

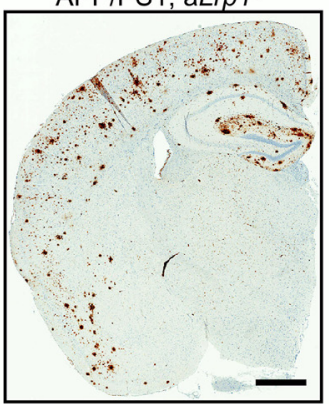

APP/PS1

$\square$ APP/PS1; $a L r p 1^{1-}$
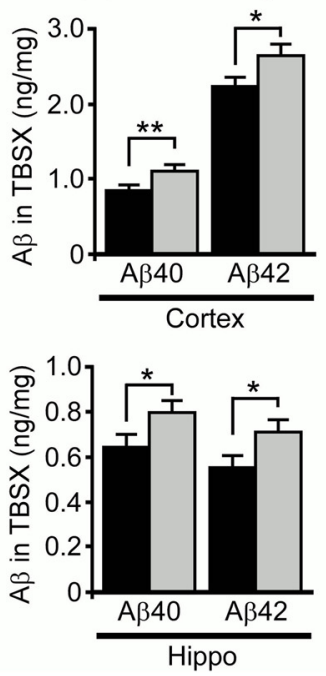

APP/PS1

$\square$ APP/PS1; $a L r p 1^{-1-}$

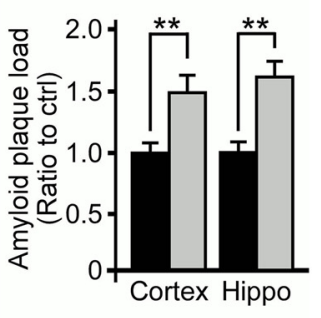

APP/PS1

$\square$ APP/PS1; aLrp1 ${ }^{-}$
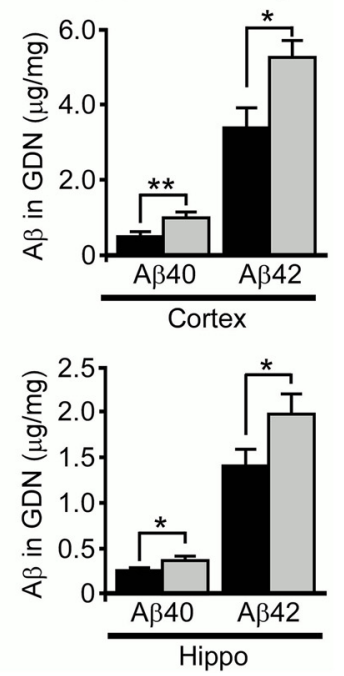

Figure 4. LRP1 deficiency in astrocytes enhances amyloid deposition in APP/PS1 mice. $A$, Brain sections obtained from 12month-old APP/PS1 and APP/PS1; aLrp $1^{-1-}$ mice were immunostained for A $\beta$. Scale bar, $1 \mathrm{~mm}$. The percentage of area covered by amyloid plaques was quantified. $\boldsymbol{B}, \boldsymbol{C}$, Cortical and hippocampal brain tissues were fractionated into TBS-soluble, detergentsoluble (TBSX), and insoluble (guanidine-HCl, GDN) fractions. A $\beta$ levels from each fraction were quantified by ELISA. Data are mean \pm SEM ( $n=9$ or 10/group). ${ }^{*} p<0.05$ (two-tailed Student's $t$ test). ${ }^{* *} p<0.01$ (two-tailed Student's $t$ test).

processing products in both APP/PS1 and APP/PS1; aLrp1 $1^{-/-}$ mice were analyzed. No significant differences were observed between the respective amounts of full-length APP (Fig. 5C) and soluble forms of APP (sAPP $\alpha$ and sAPP $\beta$; Fig. $5 D)$ in 12-monthold APP/PS1 and APP/PS1; aLrp1 $1^{-/-}$mice, suggesting that LRP1 expression does not significantly affect APP processing in these mice. In addition, previous study showed that deficiency of water channel reduces LRP1 levels in astrocytes and exacerbates brain A $\beta$ plaque deposits (Xu et al., 2015). We thus examined whether LRP1 deficiency affects AQP-4 expression. We found that deletion of astrocytic LRP1 did not significantly affect AQP-4 level in $\mathrm{APP} / \mathrm{PS} 1$; aLrp1 $1^{-/-}$mice compared with littermate control mice at 12 months of age (Fig. 5E).

\section{LRP1 deletion in astrocytes enhances neuroinflammation in amyloid model mice}

Given chronic brain inflammatory processes, mediated by the progressive activation of astrocytes and microglia with subsequent accumulation of proinflammatory cytokines, have been shown to contribute to AD pathogenesis (Wyss-Coray, 2006; Morales et al., 2014), we evaluated the inflammatory status in our astrocytic LRP1 knock-out amyloid mouse model. To examine the extent of astrogliosis in the mice, we immunostained brain sections obtained from APP/PS1; $\mathrm{aLrp1}^{-1-}$ and APP/PS1 mice with an anti-GFAP antibody. Quantification of GFAP immunostaining clearly demonstrated increased activation of astrocytes in the brains of APP/PS1; aLrp1 ${ }^{-/-}$mice compared with those of APP/PS1 mice at 12 months of age (Fig. 6A-C). The brain sections were also immunostained with antiIbal antibody to examine the extent of microgliosis; dystrophic microglial reactivity was more evident in APP/PS1; aLrp1 $1^{-/-}$ mice (Fig. $6 D-F$ ). Western blot analysis also confirmed that GFAP was significantly upregulated in APP/PS1; aLrp1 $1^{-/-}$mice (Fig. $6 G)$. LRP1 deficiency in astrocytes in the absence of APP/PS1 background did not affect GFAP levels, indicating that the increased astrogliosis was attributed to an increase in $\mathrm{A} \beta$ accumulation and amyloid deposition in APP/PS1; aLrp1 ${ }^{-/-}$mice (Fig. $6 H$ ). In addition, LRP1 deficiency in astrocytes led to an increase of TNF- $\alpha$ and interleukin- $1 \beta$ (Fig. 6I), important proinflammatory mediators involved in the development of $\mathrm{AD}$ (Morales et al., 2014). These findings demonstrate deletion of astrocytic LRP1 promotes increased neuroinflammation together with amyloid deposition.

\section{Discussion}

The link between impaired $\mathrm{A} \beta$ metabolism and $\mathrm{AD}$ continues to be intensely investigated; however, the role of astrocytes in $\mathrm{A} \beta$ production and clearance has not been fully elucidated. $\mathrm{A} \beta$ accumulation in the brain, a result of an imbalance of its production and clearance, has been shown to trigger a pathogenic cascade (Hardy and Selkoe, 2002; Blennow et al., 2006; Zheng and Koo, 2011). Given that impaired clearance of $A \beta$ is a major event in late-onset $\mathrm{AD}$ (Mawuenyega et al., 2010), which affects the vast majority of AD patients (Alzheimer'sAssociation, 2015), improved understanding of the pathways regulating $A \beta$ clearance may help to establish new targets for therapy and prevention. In this study, we sought to examine the molecular mechanisms of astrocyte-mediated $\mathrm{A} \beta$ metabolism in vivo. We found that LRP1 in primary astrocytes mediates the uptake and degradation of $\mathrm{A} \beta$ and regulates the levels of $\mathrm{A} \beta$-degrading enzymes. Our in vivo work using conditional knock-out mouse models deleting LRP1 in astrocytes in the background of amyloid model revealed a clear role of astrocytic LRP1 in brain $\mathrm{A} \beta$ clearance impacting both amyloid pathology and neuroinflammation. Our findings demonstrate a critical role of LRP1 in astrocyte-mediated $\mathrm{A} \beta$ clearance in $\mathrm{AD}$ pathogenesis.

$\mathrm{A} \beta$ is cleared in the brain by multiple pathways, including intracellular degradation by various brain cell types, and extracellular degradation by A $\beta$-degrading enzymes (Bu, 2009). Upon cellular $A \beta$ internalization, the majority of $A \beta$ is quickly delivered to lysosomes and efficiently degraded (Mandrekar et al., 2009; Li et al., 2012). LRP1 is characterized by its rapid enocytotic ability to mediate cellular uptake of a variety of ligands, including apoE, $\alpha_{2}$-macroglobulin, and tissue plasminogen activator (Herz and Strickland, 2001; $\mathrm{Bu}, 2009)$. Although it is controversial whether LRP1 can directly bind to A $\beta$ (Sagare et al., 2007; Yamada et al., 2008), LRP1 clearly regulates the endocytosis of $\mathrm{A} \beta$, albeit with a slower kinetics compared with that of another 
A

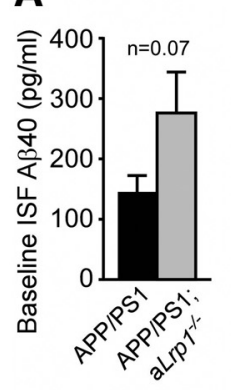

B

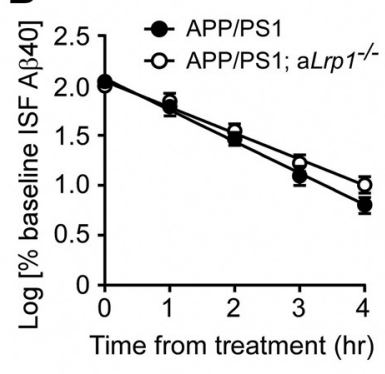

C

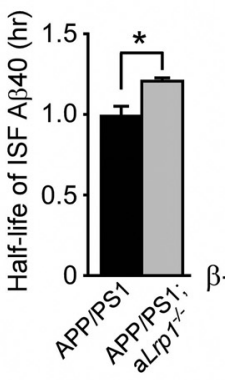

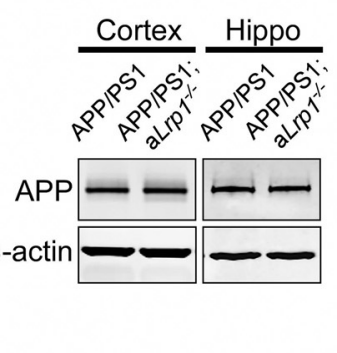

APP/PS1

APP/PS1; $a \mathrm{Lrp1}^{-/-}$

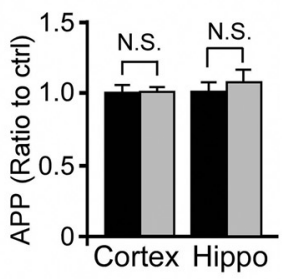

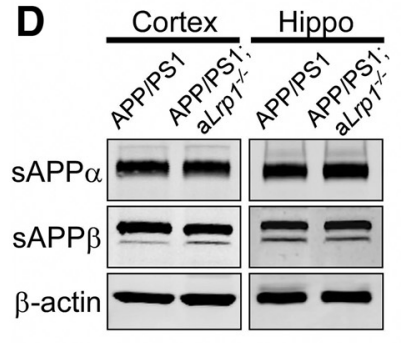
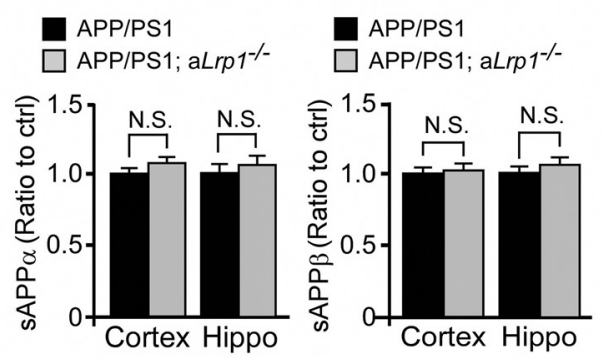

E
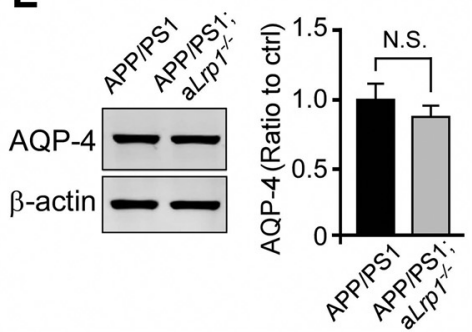

Figure 5. LRP1 deficiency in astrocytes impairs $A \beta$ clearance but not $A \beta$ production in vivo. $A, B, A \beta$ metabolism in the hippocampus of APP/PS1 and APP/PS1; $a$ Lrp $1^{-/-}$mice $(n=4 / g r o u p)$ at the age of 3-4 months was analyzed by in vivo microdialysis. $A$, Baseline $A \beta 40$ levels were measured. To assess $A \beta 40$ half-life, the mice were treated with a $\gamma$-secretase inhibitor, and the hippocampal ISF $A \beta 40$ concentrations were monitored. $\boldsymbol{B}$, The common logarithm of percentage baseline ISF $A \beta 40$ concentrations versus time was plotted. The mean ISF $A \beta$ elimination half-life $\left(t_{1 / 2}\right)$ was calculated for each mouse as the slope of the individual linear regressions from log (\% ISF A $\left.\beta 40\right)$ versus time. Data are mean \pm SEM. ${ }^{*} p<0.05$ (two-tailed Student's $t$ test). $\boldsymbol{C}, \boldsymbol{D}$, Full-length APP $(\boldsymbol{C})$ and SAPP $\alpha$ and sAPP $\beta$ levels $(\boldsymbol{D})$ in the hippocampus and cortex of APP/PS1 and APP/PS1; aLrp $1^{-/-}$mice $(n=8-10 /$ group) at 12 months of age were analyzed by Western blotting and quantified. Data are mean \pm SEM. $E$, AQP-4 in the cortex of APP/PS1 and APP/PS1; aLrp $1^{-1-}$ mice $(n=8-10 /$ group) at 12 months of age were analyzed by Western blotting and quantified. Data are mean \pm SEM.

LRP1 ligand RAP (Kanekiyo et al., 2011). Using a strain of GFAPCre mice that express Cre early in neurogenesis with the expectation to delete LRP1 in both neurons and glial cells, a previous study showed that reduced LRP1 expression in the hippocampal neurons by $\sim 50 \%$ results in early lethality in mice with no significant impact on plaque deposition (Xu et al., 2012). Utilization of the GFAP-Cre mice here (Bajenaru et al., 2002), this resulted in deletion of LRP1 in GFAP-positive astrocytes but not in NeuNpositive neurons. The discrepancy might be due to differences in Cre mouse strains, gene knock-out specificity, or efficiency. By breeding $\operatorname{Lrp} 1$ floxed mice with calcium/calmodulin-dependent protein kinase II $\alpha$ ( $\alpha$ CaMKII-Cre) mice, our previous study showed that LRP1 depletion in adult forebrain neurons impairs $\mathrm{A} \beta$ clearance (Kanekiyo et al., 2013). However, the role of astrocytic LRP1 in A $\beta$ metabolism in vivo has not been specifically addressed. Several in vitro studies have implicated an important role of astrocytes in cellular $A \beta$ metabolism. When transcription factor EB was overexpressed in astrocytes using adeno-associated virus-mediated gene delivery method in the hippocampus of $\mathrm{APP} / \mathrm{PS} 1$ mice, $\mathrm{A} \beta$ clearance was facilitated by enhancing lysosome biogenesis, resulting in reduced amyloid plaque load (Xiao et al., 2014). In human glioblastoma cells, $A \beta 42$ is shown to be internalized through fluid phase macropinocytosis, transported to lysosomes, and subjected to proteolysis, where LRP1 mediates the uptake of soluble $A \beta 42$ more efficiently than that of $A \beta 42$ aggregates (Li et al., 2014). RAP, an antagonist of the LDLR family members, effectively blocks astrocyte-mediated $\mathrm{A} \beta$ degradation in brain sections from amyloid model mice (Koistinaho et al., 2004). We found that deletion of LRP1 in astrocytes disturbed ISF $A \beta$ clearance and increased the levels of soluble $A \beta$ as well as insoluble $\mathrm{A} \beta$ in the brains of APP/PS1 mice. Although further studies are needed, LRP1 in astrocytes likely plays a critical role in the clearance of both soluble and insoluble $\mathrm{A} \beta$.
ApoE is a critical LRP1 ligand, which significantly contributes to $\mathrm{A} \beta$ pathology in $\mathrm{AD}$ pathogenesis ( $\mathrm{Bu}, 2009$; Liu et al., 2013; Hu et al., 2015). Deficiency of apoE significantly facilitates ISF A $\beta$ clearance in PDAPP mice (DeMattos et al., 2004). Furthermore, anti-apoE immunotherapy also ameliorates $\mathrm{A} \beta$ accumulation in APP/PS1 mice (Kim et al., 2012). Although multiple pathways might be involved in the mechanisms, apoE has been shown to compete with soluble A $\beta$ for LRP1-dependent cellular uptake in astrocytes (Verghese et al., 2013). Thus, endogenous apoE may compromise extracellular metabolism of soluble $\mathrm{A} \beta$ by blocking the astrocytic LRP1-mediated pathways. A recent study also showed that the phagocytic capacity of astrocytes is highly dependent on APOE isoforms (Chung et al., 2016). Whether LRP1 mediates apoE-regulated phagocytic capacity of astrocytes in synaptic pruning, and degradation of neuronal debris and amyloid warrants further investigation.

Previous studies suggest that LRP1 modulates APP endocytic trafficking, which influences $\mathrm{A} \beta$ production in various cellular models (Ulery et al., 2000; Cam et al., 2005). In addition, recent in vivo studies demonstrated that LRP1 plays an important role in modulating $\mathrm{A} \beta$ clearance. For instance, deletion of LRP1 in neurons or vascular mural cells suppresses A $\beta$ clearance in APP/PS1 mice without affecting APP processing (Kanekiyo et al., 2012, 2013). Also, LRP1 mediates A $\beta$ clearance across the blood-brain barrier (Ramanathan et al., 2015). These studies suggest that LRP1 may exhibit differential functions in regulating $A \beta$ metabolism depending on cell types and the model systems. Astrocytes represent a major cell type mediating the elimination of $A \beta$ in the brain. In our present study, deficiency of LRP1 in astrocytes disturbed A $\beta$ clearance, suggesting that the effect of LRP1 on $A \beta$ clearance may be dominant over its potentially minor role in $\mathrm{A} \beta$ production in astrocytes. Together, these studies establish a critical role of LRP1 in different brain cell types in brain $\mathrm{A} \beta$ clearance. 

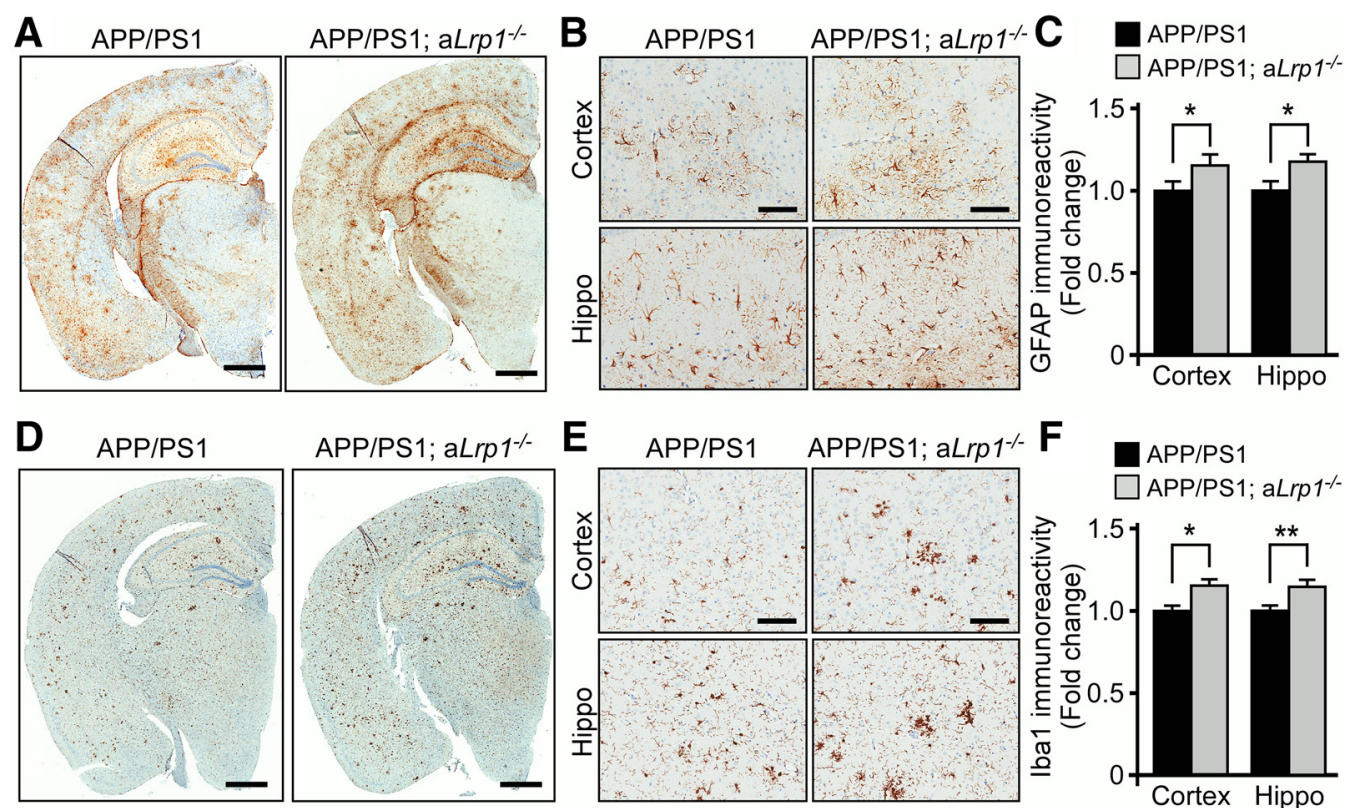

$\square$ APP/PS1; aLrp1\%
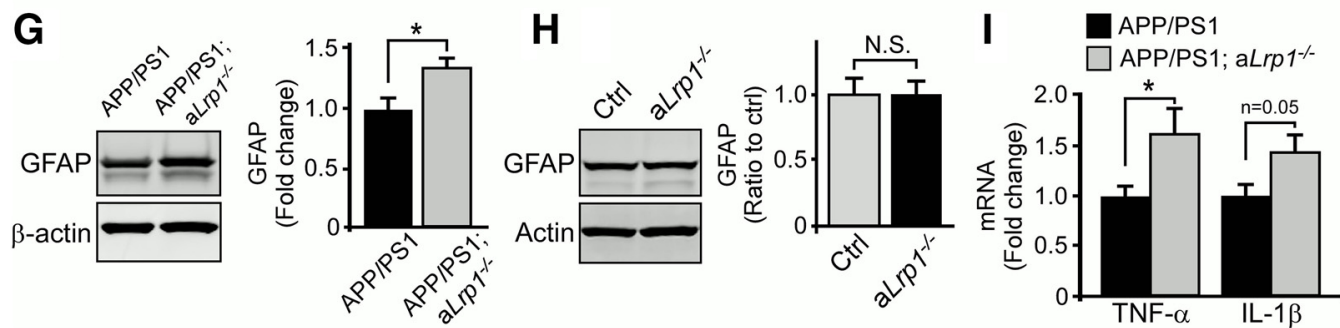

Figure 6. LRP1 deficiency in astrocytes leads to an increase in neuroinflammation. $A-C$, Brain sections from APP/PS1 and APP/PS1; alrp $1^{-/-}$mice $(n=8$ or $9 / \mathrm{group})$ at $12 \mathrm{months}$ of age were immunostained for the astrocyte marker GFAP ( $\boldsymbol{A}$ ) and quantified (C). Scale bar, $1 \mathrm{~mm}$. B. Higher-magnification images for GFAP immunostaining in the cortex and hippocampus. Scale bar, $200 \mu \mathrm{m}$. Data are mean \pm SEM. ${ }^{*} p<0.05 . \boldsymbol{D}-\boldsymbol{F}$, Brain sections from APP/PS1 and APP/PS1; aLrp1 ${ }^{-1-}$ mice $(n=8$ or $9 /$ group) were immunostained for the microglia marker Iba1 (D) and quantified (F). Scale bar, $1 \mathrm{~mm}$. $\boldsymbol{E}$, Higher-magnification images for lba1 immunostaining in the cortex and hippocampus. Scale bar, $200 \mu \mathrm{m}$. Data are mean \pm SEM. ${ }^{*} p<0.05$ (two-tailed Student's $t$ test). ${ }^{* *} p<$ 0.01 (two-tailed Student's $t$ test). G, GFAP in the cortex ( $n=9 /$ group) of APP/PS1 and APP/PS1; $a$ Lrp1 ${ }^{-/-}$mice examined by Western blotting. Data are mean \pm SEM. ${ }^{*} p<0.05$. H, GFAP in the cortex ( $n=8$ or $9 /$ group) of control and $a L r p 1^{-1-}$ mice (in the absence of APP/PS1 background) examined by Western blotting. Data are mean \pm SEM. I, TNF- $\alpha$ and interleukin- $1 \beta$ (IL-1 $\beta$ ) in the cortex of APP/PS1 and APP/PS1; aLrp1 ${ }^{-/-}$mice ( $n=9 /$ group) evaluated by real-time PCR. Data are mean \pm SEM. ${ }^{*} p<0.05$ (two-tailed Student's $t$ test).

Several $A \beta$ degrading enzymes are abundantly expressed in astrocytes (Mulder et al., 2012). In addition to cellular A $\beta$ clearance, extracellular proteolytic degradation of $\mathrm{A} \beta$ mediated by enzymes, such as neprilysin, IDE, and MMPs, also represents an important pathway in $\mathrm{A} \beta$ metabolism (Saido and Leissring, 2012). LRP1 plays an important role in regulating MMP expression and functions (Etique et al., 2013). Hepatic LRP1 was suggested to facilitate $A \beta$ degradation via various $A \beta$-degrading enzymes (Dries et al., 2012). Postmortem AD cortical brain tissues exhibit decreased levels of both LRP1 and IDE compared with those of normal aging or pathological aging individuals (Shinohara et al., 2014). In addition, IDE-mediated degradation of $A \beta$ is regulated by astrocytic apoE, a ligand for LRP1 (Jiang et al., 2008). Here, we found that knockdown of LRP1 resulted in reduced mRNA levels of IDE, MMP2, and MMP9 in primary astrocytes. Although further studies are needed to determine the molecular mechanisms underlying the interaction between LRP1 and the regulation of these enzymes, LRP1 may prevent A $\beta$ deposition by facilitating cellular $\mathrm{A} \beta$ uptake and enzymatic $\mathrm{A} \beta$ degradation in astrocytes.

Given accumulating evidence revealing the contribution of cerebrovascular damage to AD pathogenesis (Zlokovic, 2011; Nelson et al., 2016), and that end-feet of astrocytes surround cerebrovasculature to maintain blood-brain barrier integrity
(Osborn et al., 2016), future studies investigating the role of astrocytic LRP1 in cerebrovascular $\mathrm{A} \beta$ clearance may be warranted. For example, the water channel AQP-4, predominantly expressed in the end-feet of astrocytes, regulates $\mathrm{A} \beta$ accumulation, cerebral amyloid angiopathy, and synapses in APP/PS1 mice (Xu et al., 2015). Of note, deletion of AQP-4 has been shown to increase astrocyte atrophy and suppresses LRP1 expression in the astrocytes surrounding A $\beta$ plaques (Yang et al., 2012; Xu et al., 2015). Our results showed that deletion of LRP1 in the astrocytes did not significantly alter the levels of AQP-4, suggesting that AQP-4 may function in the upstream of LRP1 in astrocytes. However, we cannot rule out the possibility that astrocytic LRP1 and AQP-4 function cooperatively in mediating ISF $A \beta$ clearance along the cerebrovasculature drainage pathway. Future studies are needed to understand whether LRP1 and AQP-4 exhibit a functional interaction and whether upregulation of LRP1 expression and/or function in astrocytes can rescue the deficits of $A \beta$ metabolism resulted from $\mathrm{AQP}-4$ deficiency.

In conclusion, we demonstrate the significant contribution of astrocytic LRP1 to $\mathrm{A} \beta$ metabolism using both in vitro and in vivo models, thereby expanding upon recent findings of LRP1's critical role in neurons (Kanekiyo et al., 2013), vascular mural cells (Kanekiyo et al., 2012), and endothelial cells (Storck et al., 2016). Astrocytic LRP1 deficiency results in impaired ISF A $\beta$ elimina- 
tion and aggravated $\mathrm{A} \beta$ deposition in the brains of APP/PS1 mice; the suppression of both astrocytic intracellular degradation and extracellular clearance of $A \beta$ via $A \beta$ degrading enzymes likely mediates these effects. Given that LRP1 levels are shown to be decreased in $\mathrm{AD}$ brains compared with control individuals (Kang et al., 2000), restoring LRP1 expression and functions could be an effective strategy to facilitate $A \beta$ clearance and counter amyloid pathology in AD. Future studies designed to develop pharmacological approaches and gene therapies targeting astrocytic LRP1 may hold promises as means to combat $\mathrm{AD}$.

\section{References}

Alzheimer's Association (2015) 2015 Alzheimer's disease facts and figures. Alzheimers Dement 11:332-384. CrossRef Medline

Backstrom JR, Lim GP, Cullen MJ, Tökés ZA (1996) Matrix metalloproteinase-9 (MMP-9) is synthesized in neurons of the human hippocampus and is capable of degrading the amyloid-beta peptide (1-40). J Neurosci 16:7910-7919. Medline

Bajenaru ML, Zhu Y, Hedrick NM, Donahoe J, Parada LF, Gutmann DH (2002) Astrocyte-specific inactivation of the neurofibromatosis 1 gene (NF1) is insufficient for astrocytoma formation. Mol Cell Biol 22:51005113. CrossRef Medline

Blennow K, de Leon MJ, Zetterberg H (2006) Alzheimer's disease. Lancet 368:387-403. CrossRef Medline

Bu G (2009) Apolipoprotein E and its receptors in Alzheimer's disease: pathways, pathogenesis and therapy. Nat Rev Neurosci 10:333-344. CrossRef Medline

Bu G, Geuze HJ, Strous GJ, Schwartz AL (1995) 39 kDa receptor-associated protein is an ER resident protein and molecular chaperone for LDL receptor-related protein. EMBO J 14:2269-2280. Medline

Cam JA, Zerbinatti CV, Li Y, Bu G (2005) Rapid endocytosis of the low density lipoprotein receptor-related protein modulates cell surface distribution and processing of the beta-amyloid precursor protein. J Biol Chem 280:15464-15470. CrossRef Medline

Chung WS, Verghese PB, Chakraborty C, Joung J, Hyman BT, Ulrich JD, Holtzman DM, Barres BA (2016) Novel allele-dependent role for APOE in controlling the rate of synapse pruning by astrocytes. Proc Natl Acad Sci U S A 113:10186-10191. CrossRef Medline

Cirrito JR, May PC, O’Dell MA, Taylor JW, Parsadanian M, Cramer JW, Audia JE, Nissen JS, Bales KR, Paul SM, DeMattos RB, Holtzman DM (2003) In vivo assessment of brain interstitial fluid with microdialysis reveals plaque-associated changes in amyloid-beta metabolism and halflife. J Neurosci 23:8844-8853. Medline

Cirrito JR, Disabato BM, Restivo JL, Verges DK, Goebel WD, Sathyan A, Hayreh D, D’Angelo G, Benzinger T, Yoon H, Kim J, Morris JC, Mintun MA, Sheline YI (2011) Serotonin signaling is associated with lower amyloid-beta levels and plaques in transgenic mice and humans. Proc Natl Acad Sci U S A 108:14968-14973. CrossRef Medline

Das P, Verbeeck C, Minter L, Chakrabarty P, Felsenstein K, Kukar T, Maharvi G, Fauq A, Osborne BA, Golde TE (2012) Transient pharmacologiclowering of Abeta production prior to deposition results in sustained reduction of amyloid plaque pathology. Mol Neurodegener 7:39. CrossRef Medline

DeMattos RB, Cirrito JR, Parsadanian M, May PC, O’Dell MA, Taylor JW, Harmony JA, Aronow BJ, Bales KR, Paul SM, Holtzman DM (2004) ApoE and clusterin cooperatively suppress Abeta levels and deposition: evidence that ApoE regulates extracellular Abeta metabolism in vivo. Neuron 41:193-202. CrossRef Medline

Dries DR, Yu G, Herz J (2012) Extracting beta-amyloid from Alzheimer's disease. Proc Natl Acad Sci U S A 109:3199-3200. CrossRef Medline

Etique N, Verzeaux L, Dedieu S, Emonard H (2013) LRP-1: a checkpoint for the extracellular matrix proteolysis. Biomed Res Int 2013:152163. CrossRef Medline

Fu Y, Zhao J, Atagi Y, Nielsen HM, Liu CC, Zheng H, Shinohara M, Kanekiyo $\mathrm{T}, \mathrm{Bu} \mathrm{G}$ (2016) Apolipoprotein E lipoprotein particles inhibit amyloidbeta uptake through cell surface heparan sulphate proteoglycan. Mol Neurodegener 11:37. CrossRef Medline

Hardy J, Selkoe DJ (2002) The amyloid hypothesis of Alzheimer's disease: progress and problems on the road to therapeutics. Science 297:353-356. CrossRef Medline

Herz J, Strickland DK (2001) LRP: a multifunctional scavenger and signaling receptor. J Clin Invest 108:779-784. CrossRef Medline

Hu J, Liu CC, Chen XF, Zhang YW, Xu H, Bu G (2015) Opposing effects of viral mediated brain expression of apolipoprotein E2 (apoE2) and apoE4 on apoE lipidation and Abeta metabolism in apoE4-targeted replacement mice. Mol Neurodegener 10:6. CrossRef Medline

Jankowsky JL, Fadale DJ, Anderson J, Xu GM, Gonzales V, Jenkins NA, Copeland NG, Lee MK, Younkin LH, Wagner SL, Younkin SG, Borchelt DR (2004) Mutant presenilins specifically elevate the levels of the 42 residue beta-amyloid peptide in vivo: evidence for augmentation of a 42-specific gamma secretase. Hum Mol Genet 13:159-170. CrossRef Medline

Jiang Q, Lee CY, Mandrekar S, Wilkinson B, Cramer P, Zelcer N, Mann K, Lamb B, Willson TM, Collins JL, Richardson JC, Smith JD, Comery TA, Riddell D, Holtzman DM, Tontonoz P, Landreth GE (2008) ApoE promotes the proteolytic degradation of Abeta. Neuron 58:681-693. CrossRef Medline

Kanekiyo T, Bu G (2014) The low-density lipoprotein receptor-related protein 1 and amyloid-beta clearance in Alzheimer's disease. Front Aging Neurosci 6:93. CrossRef Medline

Kanekiyo T, Zhang J, Liu Q, Liu CC, Zhang L, Bu G (2011) Heparan sulphate proteoglycan and the low-density lipoprotein receptor-related protein 1 constitute major pathways for neuronal amyloid-beta uptake. J Neurosci 31:1644-1651. CrossRef Medline

Kanekiyo T, Liu CC, Shinohara M, Li J, Bu G (2012) LRP1 in brain vascular smooth muscle cells mediates local clearance of Alzheimer's amyloidbeta. J Neurosci 32:16458-16465. CrossRef Medline

Kanekiyo T, Cirrito JR, Liu CC, Shinohara M, Li J, Schuler DR, Holtzman DM, Bu G (2013) Neuronal clearance of amyloid-beta by endocytic receptor LRP1. J Neurosci 33:19276-19283. CrossRef Medline

Kang DE, Pietrzik CU, Baum L, Chevallier N, Merriam DE, Kounnas MZ, Wagner SL, Troncoso JC, Kawas CH, Katzman R, Koo EH (2000) Modulation of amyloid beta-protein clearance and Alzheimer's disease susceptibility by the LDL receptor-related protein pathway. J Clin Invest 106: 1159-1166. CrossRef Medline

Kim J, Eltorai AE, Jiang H, Liao F, Verghese PB, Stewart FR, Basak JM, Holtzman DM (2012) Anti-apoE immunotherapy inhibits amyloid accumulation in a transgenic mouse model of Abeta amyloidosis. J Exp Med 209:2149-2156. CrossRef Medline

Koistinaho M, Lin S, Wu X, Esterman M, Koger D, Hanson J, Higgs R, Liu F, Malkani S, Bales KR, Paul SM (2004) Apolipoprotein E promotes astrocyte colocalization and degradation of deposited amyloid-beta peptides. Nat Med 10:719-726. CrossRef Medline

Kraft AW, Hu X, Yoon H, Yan P, Xiao Q, Wang Y, Gil SC, Brown J, Wilhelmsson U, Restivo JL, Cirrito JR, Holtzman DM, Kim J, Pekny M, Lee JM (2013) Attenuating astrocyte activation accelerates plaque pathogenesis in APP/PS1 mice. FASEB J 27:187-198. CrossRef Medline

Leissring MA, Farris W, Chang AY, Walsh DM, Wu X, Sun X, Frosch MP, Selkoe DJ (2003) Enhanced proteolysis of beta-amyloid in APP transgenic mice prevents plaque formation, secondary pathology, and premature death. Neuron 40:1087-1093. CrossRef Medline

Li J, Kanekiyo T, Shinohara M, Zhang Y, LaDu MJ, Xu H, Bu G (2012) Differential regulation of amyloid-beta endocytic trafficking and lysosomal degradation by apolipoprotein E isoforms. J Biol Chem 287:4459344601. CrossRef Medline

Li Y, Cheng D, Cheng R, Zhu X, Wan T, Liu J, Zhang R (2014) Mechanisms of U87 astrocytoma cell uptake and trafficking of monomeric versus protofibril Alzheimer's disease amyloid-beta proteins. PLoS One 9:e99939. CrossRef Medline

Liu CC, Kanekiyo T, Xu H, Bu G (2013) Apolipoprotein E and Alzheimer disease: risk, mechanisms and therapy. Nat Rev Neurol 9:106-118. CrossRef Medline

Liu CC, Tsai CW, Deak F, Rogers J, Penuliar M, Sung YM, Maher JN, Fu Y, Li X, Xu H, Estus S, Hoe HS, Fryer JD, Kanekiyo T, Bu G (2014) Deficiency in LRP6-mediated Wnt signaling contributes to synaptic abnormalities and amyloid pathology in Alzheimer's disease. Neuron 84:63-77. CrossRef Medline

Liu CC, Hu J, Tsai CW, Yue M, Melrose HL, Kanekiyo T, Bu G (2015) Neuronal LRP1 regulates glucose metabolism and insulin signaling in the brain. J Neurosci 35:5851-5859. CrossRef Medline

Liu CC, Zhao N, Yamaguchi Y, Cirrito JR, Kanekiyo T, Holtzman DM, Bu G (2016) Neuronal heparan sulfates promote amyloid pathology by modulating brain amyloid-beta clearance and aggregation in Alzheimer's disease. Sci Transl Med 8:332ra344. CrossRef Medline

Liu Q, Zerbinatti CV, Zhang J, Hoe HS, Wang B, Cole SL, Herz J, Muglia L, Bu G (2007) Amyloid precursor protein regulates brain apolipoprotein $\mathrm{E}$ 
and cholesterol metabolism through lipoprotein receptor LRP1. Neuron 56:66-78. CrossRef Medline

Mandrekar S, Jiang Q, Lee CY, Koenigsknecht-Talboo J, Holtzman DM, Landreth GE (2009) Microglia mediate the clearance of soluble Abeta through fluid phase macropinocytosis. J Neurosci 29:4252-4262. CrossRef Medline

Mawuenyega KG, Sigurdson W, Ovod V, Munsell L, Kasten T, Morris JC, Yarasheski KE, Bateman RJ (2010) Decreased clearance of CNS betaamyloid in Alzheimer's disease. Science 330:1774. CrossRef Medline

Meraz-Ríos MA, Toral-Rios D, Franco-Bocanegra D, Villeda-Hernández J, Campos-Peña V (2013) Inflammatory process in Alzheimer's disease. Front Integr Neurosci 7:59. Medline

Morales I, Guzmán-Martínez L, Cerda-Troncoso C, Farías GA, Maccioni RB (2014) Neuroinflammation in the pathogenesis of Alzheimer's disease: a rational framework for the search of novel therapeutic approaches. Front Cell Neurosci 8:112. CrossRef Medline

Mulder SD, Veerhuis R, Blankenstein MA, Nielsen HM (2012) The effect of amyloid associated proteins on the expression of genes involved in amyloid-beta clearance by adult human astrocytes. Exp Neurol 233:373379. CrossRef Medline

Nelson AR, Sweeney MD, Sagare AP, Zlokovic BV (2016) Neurovascular dysfunction and neurodegeneration in dementia and Alzheimer's disease. Biochim Biophys Acta 1862:887-900. CrossRef Medline

Nielsen HM, Mulder SD, Beliën JA, Musters RJ, Eikelenboom P, Veerhuis R (2010) Astrocytic A beta 1-42 uptake is determined by A betaaggregation state and the presence of amyloid-associated proteins. Glia 58:1235-1246. CrossRef Medline

Osborn LM, Kamphuis W, Wadman WJ, Hol EM (2016) Astrogliosis: an integral player in the pathogenesis of Alzheimer's disease. Prog Neurobiol 144:121-141. CrossRef Medline

Ramanathan A, Nelson AR, Sagare AP, Zlokovic BV (2015) Impaired vascular-mediated clearance of brain amyloid beta in Alzheimer's disease: the role, regulation and restoration of LRP1. Front Aging Neurosci 7:136. CrossRef Medline

Rohlmann A, Gotthardt M, Hammer RE, Herz J (1998) Inducible inactivation of hepatic LRP gene by cre-mediated recombination confirms role of LRP in clearance of chylomicron remnants. J Clin Invest 101:689-695. CrossRef Medline

Sagare A, Deane R, Bell RD, Johnson B, Hamm K, Pendu R, Marky A, Lenting PJ, Wu Z, Zarcone T, Goate A, Mayo K, Perlmutter D, Coma M, Zhong Z, Zlokovic BV (2007) Clearance of amyloid-beta by circulating lipoprotein receptors. Nat Med 13:1029-1031. CrossRef Medline

Saido T, Leissring MA (2012) Proteolytic degradation of amyloid betaprotein. Cold Spring Harb Perspect Med 2:a006379. CrossRef Medline

Serrano-Pozo A, Mielke ML, Gómez-Isla T, Betensky RA, Growdon JH, Frosch MP, Hyman BT (2011) Reactive glia not only associates with plaques but also parallels tangles in Alzheimer's disease. Am J Pathol 179:13731384. CrossRef Medline

Shinohara M, Fujioka S, Murray ME, Wojtas A, Baker M, Rovelet-Lecrux A, Rademakers R, Das P, Parisi JE, Graff-Radford NR, Petersen RC, Dickson DW, Bu G (2014) Regional distribution of synaptic markers and APP correlate with distinct clinicopathological features in sporadic and familial Alzheimer's disease. Brain 137:1533-1549. CrossRef Medline

Sofroniew MV, Vinters HV (2010) Astrocytes: biology and pathology. Acta Neuropathol 119:7-35. CrossRef Medline

Song H, Li Y, Lee J, Schwartz AL, Bu G (2009) Low-density lipoprotein receptor-related protein 1 promotes cancer cell migration and invasion by inducing the expression of matrix metalloproteinases 2 and 9. Cancer Res 69:879-886. CrossRef Medline

Stewart SA, Dykxhoorn DM, Palliser D, Mizuno H, Yu EY, An DS, Sabatini DM, Chen IS, Hahn WC, Sharp PA, Weinberg RA, Novina CD (2003) Lentivirus-delivered stable gene silencing by RNAi in primary cells. RNA 9:493-501. CrossRef Medline
Storck SE, Meister S, Nahrath J, Meißner JN, Schubert N, Di Spiezio A, Baches S, Vandenbroucke RE, Bouter Y, Prikulis I, Korth C, Weggen S, Heimann A, Schwaninger M, Bayer TA, Pietrzik CU (2016) Endothelial LRP1 transports amyloid-beta1-42 across the blood-brain barrier. J Clin Invest 126:123-136. CrossRef Medline

Ulery PG, Beers J, Mikhailenko I, Tanzi RE, Rebeck GW, Hyman BT, Strickland DK (2000) Modulation of beta-amyloid precursor protein processing by the low density lipoprotein receptor-related protein (LRP): evidence that LRP contributes to the pathogenesis of Alzheimer's disease. J Biol Chem 275:7410-7415. CrossRef Medline

Verghese PB, Castellano JM, Garai K, Wang Y, Jiang H, Shah A, Bu G, Frieden C, Holtzman DM (2013) ApoE influences amyloid-beta (Abeta) clearance despite minimal apoE/Abeta association in physiological conditions. Proc Natl Acad Sci U S A 110:E1807-E1816. CrossRef Medline

Wang DD, Bordey A (2008) The astrocyte odyssey. Prog Neurobiol 86:342367. CrossRef Medline

Wyss-Coray T (2006) Inflammation in Alzheimer disease: driving force, bystander or beneficial response? Nat Med 12:1005-1015. Medline

Wyss-Coray T, Loike JD, Brionne TC, Lu E, Anankov R, Yan F, Silverstein SC, Husemann J (2003) Adult mouse astrocytes degrade amyloid-beta in vitro and in situ. Nat Med 9:453-457. CrossRef Medline

Xiao Q, Yan P, Ma X, Liu H, Perez R, Zhu A, Gonzales E, Burchett JM, Schuler DR, Cirrito JR, Diwan A, Lee JM (2014) Enhancing astrocytic lysosome biogenesis facilitates Abeta clearance and attenuates amyloid plaque pathogenesis. J Neurosci 34:9607-9620. CrossRef Medline

Xu G, Green CC, Fromholt SE, Borchelt DR (2012) Reduction of lowdensity lipoprotein receptor-related protein (LRP1) in hippocampal neurons does not proportionately reduce, or otherwise alter, amyloid deposition in APPswe/PS1dE9 transgenic mice. Alzheimers Res Ther 4:12. CrossRef Medline

Xu Z, Xiao N, Chen Y, Huang H, Marshall C, Gao J, Cai Z, Wu T, Hu G, Xiao M (2015) Deletion of aquaporin-4 in APP/PS1 mice exacerbates brain Abeta accumulation and memory deficits. Mol Neurodegener 10:58. CrossRef Medline

Yamada K, Hashimoto T, Yabuki C, Nagae Y, Tachikawa M, Strickland DK, Liu Q, Bu G, Basak JM, Holtzman DM, Ohtsuki S, Terasaki T, Iwatsubo T (2008) The low density lipoprotein receptor-related protein 1 mediates uptake of amyloid beta peptides in an in vitro model of the blood-brain barrier cells. J Biol Chem 283:34554-34562. CrossRef Medline

Yang W, Wu Q, Yuan C, Gao J, Xiao M, Gu M, Ding J, Hu G (2012) Aquaporin-4 mediates astrocyte response to beta-amyloid. Mol Cell Neurosci 49:406-414. CrossRef Medline

Yin KJ, Cirrito JR, Yan P, Hu X, Xiao Q, Pan X, Bateman R, Song H, Hsu FF, Turk J, Xu J, Hsu CY, Mills JC, Holtzman DM, Lee JM (2006) Matrix metalloproteinases expressed by astrocytes mediate extracellular amyloid-beta peptide catabolism. J Neurosci 26:10939-10948. CrossRef Medline

Youmans KL, Leung S, Zhang J, Maus E, Baysac K, Bu G, Vassar R, Yu C, LaDu MJ (2011) Amyloid-beta42 alters apolipoprotein E solubility in brains of mice with five familial AD mutations. J Neurosci Methods 196: 51-59. CrossRef Medline

Zhao J, Fu Y, Liu CC, Shinohara M, Nielsen HM, Dong Q, Kanekiyo T, Bu G (2014) Retinoic acid isomers facilitate apolipoprotein E production and lipidation in astrocytes through the retinoid X receptor/retinoic acid receptor pathway. J Biol Chem 289:11282-11292. CrossRef Medline

Zheng H, Koo EH (2011) Biology and pathophysiology of the amyloid precursor protein. Mol Neurodegener 6:27. CrossRef Medline

Zlokovic BV (2011) Neurovascular pathways to neurodegeneration in Alzheimer's disease and other disorders. Nat Rev Neurosci 12:723738. CrossRef Medline 